\title{
What is new in otitis media?
}

\author{
Lucien Corbeel
}

Received: 16 January 2007 / Accepted: 22 February 2007 / Published online: 16 March 2007

(C) Springer-Verlag 2007

\begin{abstract}
The "wait and see" approach in acute otitis media (AOM), consisting of postponing the antibiotic administration for a few days, has been advocated mainly to counteract the increased bacterial resistance in respiratory infections. This approach is not justified in children less than 2 years of age and this for several reasons. First, AOM is an acute inflammation of the middle ear caused in about $70 \%$ of cases by bacteria. Redness and bulging of the tympanic membrane are characteristic findings in bacterial AOM. Second, AOM is associated with long-term dysfunction of the inflamed eustachian tube (ET), particularly in children less than 2 years of age. In this age group, the small calibre of the ET together with its horizontal direction result in impaired clearance, ventilation and protection of the middle ear. Third, recent prospective studies have shown poor long-term prognosis of AOM in children below 2 years with at least $50 \%$ of recurrences and persisting otitis media with effusion (OME) in about $35 \%$ 6 months after AOM. Viruses elicit AOM in about $30 \%$ of children. A prolonged course of AOM has been observed when bacterial and viral infections are combined because viral infection is also associated with ET dysfunction in young children. Bacterial and viral testing of the nasopharyngeal aspirate is an excellent tool both for initial treatment and recurrence of AOM. Antibiotic treatment of AOM is mandatory in children less than 2 years of age to decrease inflammation in the middle ear but also of the ET particularly during the first episode. The best choice is amoxicillin because of its superior penetration in the middle ear. Streptococci pneumoniae with intermediary bacterial
\end{abstract}

L. Corbeel $(\bowtie)$

Department of Pediatrics, University Hospital,

Herestraat 49,

3000 Leuven, Belgium

e-mail: lucien.corbeel@med.kuleuven.be resistance to penicillin are particularly associated with recurrent AOM. Therefore the dosage of amoxicillin should be $90 \mathrm{mg} / \mathrm{kg}$ per day in three doses. In recurrent AOM with $\beta$-lactamase-producing bacilli, amoxicillin should be associated with clavulanic acid at a dose of $6.4 \mathrm{mg} / \mathrm{kg}$ per day. The duration of the treatment is not established yet but 10 days is reasonable for a first episode of AOM. OME may be a precursor initiating AOM but also a complication thereof. OME needs a watchful waiting approach. When associated with deafness for 2-3 months in children over 2 years of age, an antibiotic should be given according to the results of the bacterial resistance in the nasopharyngeal aspirate. The high rate of complications of tympanostomy tube insertion outweighs the beneficial effect on hearing loss. The poor results of this procedure are due to the absence of effects on ET dysfunction. Pneumococcal vaccination has little beneficial effects on recurrent AOM and its use in infants needs further studies. Treatment with amoxicillin is indicated in all children younger than 2 years with a first episode of AOM presenting with redness and bulging of the tympanic membrane. Combined amoxicillin and clavulanic acid should be given in patients with $\beta$ lactamase-producing bacteria. The duration of treatment is estimated to be at least 10 days depending on the findings by pneumo-otoscopy and tympanometry. Bacterial and viral testing of the nasopharyngeal aspirate is highly recommended particularly in children in day care centres as well as for regular follow-up. The high recurrence rate is due to the long-lasting dysfunction of the eustachian tube and the immune immaturity of children less than 2 years of age.

Keywords Acute otitis media - Otitis media with effusion . Eustachian tube dysfunction - Vaccination .

Tympanostomy tube insertion - Otitis media in infants .

Mastoiditis · AOM · OME · Guidelines for treatment 


\section{Abbreviations \\ AOM acute otitis media \\ OME otitis media with effusion \\ ET eustachian tube \\ MEF middle ear effusion \\ RSV respiratory syncytial virus \\ SMZ sulfamethoxazole \\ TMP trimethoprim}

\section{Introduction}

The number of publications relating to acute otitis media $(\mathrm{AOM})$ and otitis media with effusion (OME) has been increasing markedly within the last 2 years [40-49]. It points to the difficulties in giving generally accepted guidelines for treatment. The confusion can be partially explained by the absence of uniform definitions and inhomogeneous groups of patients being included in clinical studies.

$\mathrm{AOM}$ is an acute inflammation of the middle ear, frequently elicited by viral infections and characterized by redness and bulging of the tympanum. Infections with bacteria can be identified in at least $70 \%$ of the cases by culture of the middle ear purulent fluid containing mainly polymorphonuclear cells [35].

OME is an effusion of the middle ear without symptoms of acute inflammations such as pain and fever, with frequently an amber or opaque aspect of the tympanum, the effusion containing mainly macrophages. Retraction of the tympanum with the light reflex still present may render the diagnosis difficult. Cultures for bacteria are positive in about $50 \%$ of cases whereas viruses have been identified in about 30\% [35]. OME may be a precursor event initiating suppurate AOM but it can be the continuum of $\mathrm{AOM}$ as well. OME is the direct consequence of impaired middle ear ventilation.

Tympanometry (Fig. 1) shows a flat curve type $\mathrm{b}$ in both $\mathrm{AOM}$ and OME. In contrast, in OME associated with incomplete obstruction of the eustachian tube (ET) a curve $\mathrm{c}$ with a peak in the negative pressure zone is observed. Moreover, lower peak height and greater width in the negative pressure zone are frequent findings in OME [54].

This overview summarizes the main new findings about $\mathrm{AOM}$ and OME which are in accordance with some basic well-known but sometimes forgotten data and facts, with particular emphasis on the vulnerability of young children below the age of 2 years.
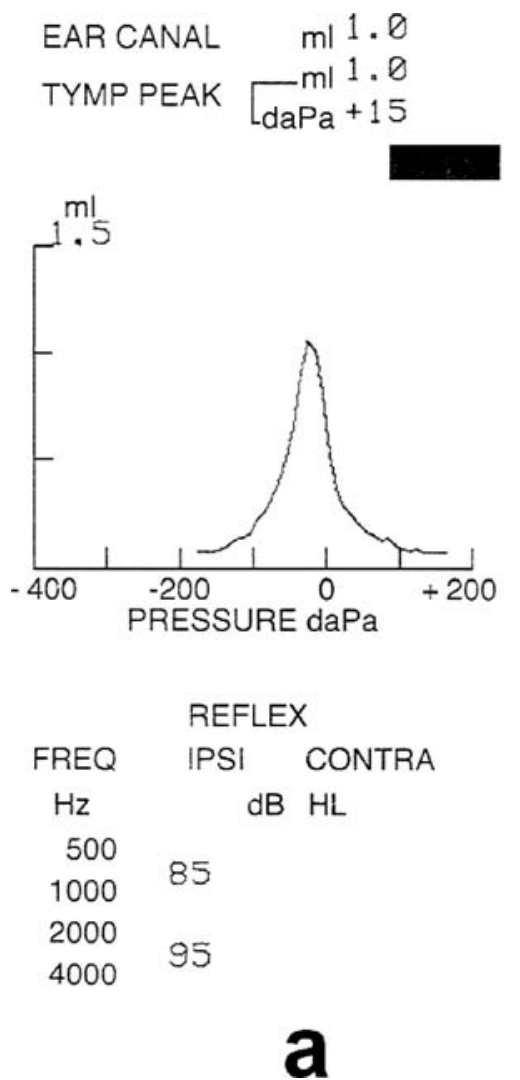

Fig. 1 The three main types of tympanograms showing: a a peak near atmospheric pressure expressed in daPa with stapedius reflex for different $\mathrm{Hz}$ frequencies, $\mathbf{b}$ a flat curve without stapedius reflex for $500,2000,4000 \mathrm{~Hz}$ pointing to presence of middle ear exudate: AOM
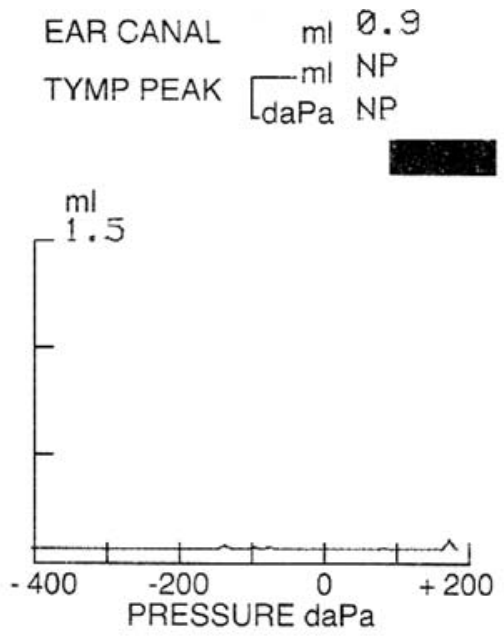

\begin{tabular}{|c|c|c|}
\hline \multicolumn{3}{|c|}{ REFLEX } \\
\hline FREQ & $|P S|$ & CONTRA \\
\hline $\mathrm{Hz}$ & $\mathrm{dB}$ & $\mathrm{HL}$ \\
\hline 500 & NR & NR \\
\hline 1000 & 95 & NR \\
\hline 2000 & NR & NR \\
\hline 4000 & NR & NT \\
\hline
\end{tabular}

b

or OME, $\mathbf{c}$ a lower peak in the negative pressure zone $(-235 \mathrm{daPa})$ with an enlarged width pointing to OME with partial permeability of ET to air entrance and still a stapedius reflex 


\section{Aetiopathogenesis}

Role of the eustachian tube

The great importance of the first attack of AOM in young children lies in the subsequent long-lasting dysfunction of the ET. Indeed, the main functions of the ET are ventilation, protection and clearance of the middle ears (Fig. 2) [5, 35] and play a determining role in the recurrence of AOM. Ventilation of the middle ear occurs by each deglutition by action of the tensor velum palatinum muscle leading to air equilibration with the atmospheric pressure. By obstruction of the ET, a negative pressure develops inside the middle ear resulting in effusion and aspiration of nasopharyngeal secretions. Poor ventilation leads to decreased $\mathrm{PO}_{2}$ which results in decreased bactericide power of polymorphonuclear cells. Impaired clearance results in proliferation not only of aerobic but also anaerobic bacteria in the middle ear. Conversely, reflux otitis occurs with decreased compliance of the ET due to abnormal flaccidity.

Fig. 2 Three physiologic functions of the eustachian tube in relation to the middle ear. $N P$ nasopharynx, ET eustachian tube, TVP tensor velum palatinum muscle, $M E$ middle ear, MAST mastoid, TM tympanic membrane, $E C$ external canal
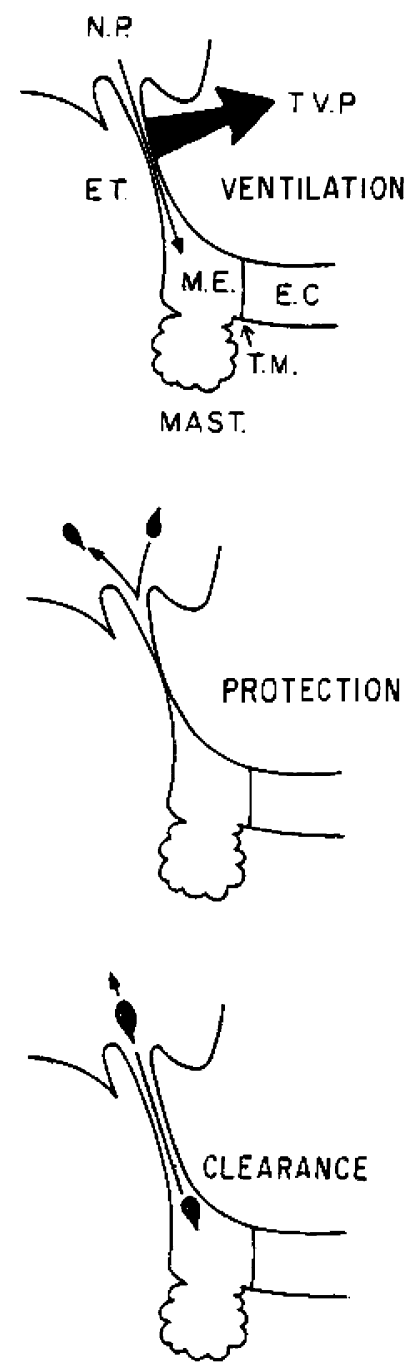

ET dysfunction is a major problem in the young child: the small calibre of the ET as well as its horizontal direction [5] (Figs. 3 and 4) are responsible for both the high incidence of $\mathrm{AOM}$ and the frequent relapses by each viral infection. This explains the poor long-term prognosis evidenced in a prospective study comprising 210 AOM patients of less than 2 years of age by Damoiseaux et al. [16]. At least $50 \%$ of the patients had recurrences of $\mathrm{AOM}$ and persistence of OME was observed in $47 \%$ of them after 3 months and in $35 \%$ after 6 months. Yet, only $50 \%$ of these patients were treated with amoxicillin. Unfortunately, the authors do not mention either the delay of treatment or the dosage of the antibiotic.

In other words, the first episode of AOM determines the evolution and the recurrences because of the associated acute inflammation involving also the ET.

Role of viruses and bacteria

\section{Viruses}

Most children are infected with respiratory syncytial virus (RSV) in their first year of life. A prospective study [2] in 42 children aged 2-24 months with bronchiolitis showed that 26 of them had AOM at entry or within 10 days and an additional 10 developed OME; only 6 patients remained free of both AOM and OME during a 3-week observation period. These findings were confirmed in a recent study showing that in patients with persistent RSV antigen in the middle ear effusion, $31 \%$ relapsed despite a favourable outcome of the first AOM episode [50].

The association of AOM with several viral infections has been largely documented. The prevalence of respiratory viruses in the middle ear fluid of 456 children, aged 7 months to 7 years, with AOM was $41 \%$ [21]. RSV was the most frequent virus isolated followed by parainfluenza, influenza, enteroviruses and adenoviruses. These findings have been confirmed by others $[18,32,33,41,50]$ and rhinovirus, coronavirus and metapneumovirus should be added to the above-mentioned list [53]. Even the measles virus has recently been isolated from the middle ear fluid in two patients [64].

\section{Bacteria}

In $70 \%$ of patients with $\mathrm{AOM}$, bacteria can be found by culturing the middle ear fluid [35]. The most frequent species isolated are Haemophilus influenzae and Streptococcus pneumoniae [27]. Nasopharyngeal aspirate culture may give valuable information on the bacteria involved in AOM [28, $51,55,58]$. The presence of conjunctivitis points to Haemophilus influenzae infection [4].

Heikkinen et al. found Streptococcus pneumoniae in $25 \%$ of their patients, Haemophilus influenzae in $23 \%$ and 
Fig. 3 The difference in the angle of the eustachian tube between infants and adults [5]

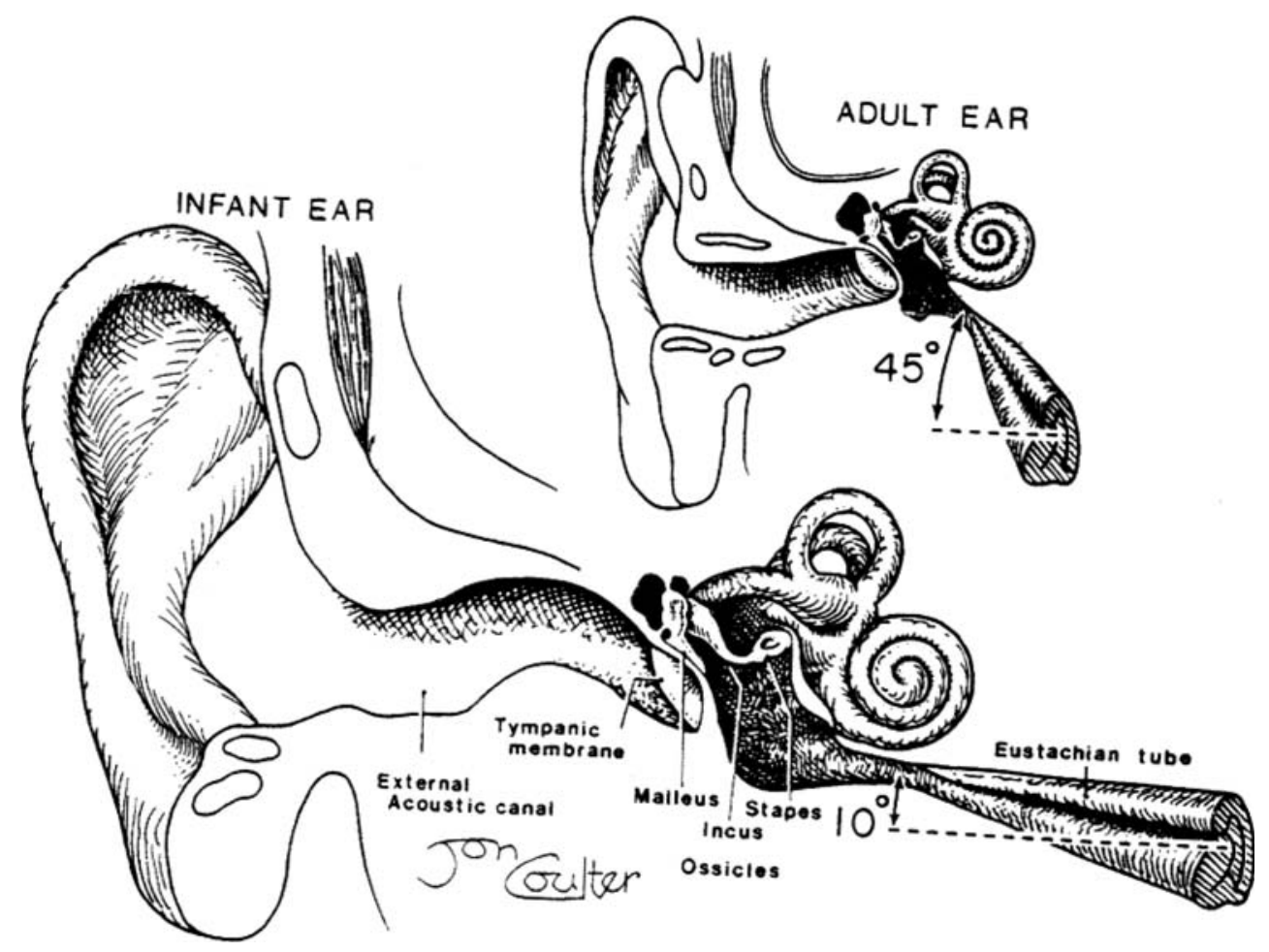

Moraxella catarrhalis in 15\% [21]. It has been demonstrated that recurrences of AOM are associated with positive bacterial culture in the nasopharynx [23], even at the end of the antibiotic treatment [28] and in most cases the pathogen was Streptococcus pneumoniae [58]. However, recurrence more than 14 days after an initial AOM episode is mostly due to a new infection, i.e. not a true relapse [27]. In a most recent prospective study on purulent meningitis [11], the association of AOM was found in half of the patients [14].

\section{Bacteria and viruses}

Bulut et al. performed both bacterial and viral testing in 120 children with AOM [8]. These patients, aged between
Fig. 4 The tympanic membrane forms the lateral wall of the boxshaped middle ear. The function of the eustachian tube is to equilibrate middle ear pressure with that in the nasopharynx. Bacteria and viruses resident in the nasopharynx may reach the middle ear during pressure equilibration. One-third of the middle ear mucosa and the entire eustachian tube are lined with mucociliary epithelium to transport bacteria from the middle ear back to the nasopharynx. Air from the middle ear enters the mastoid air cells by way of the aditus

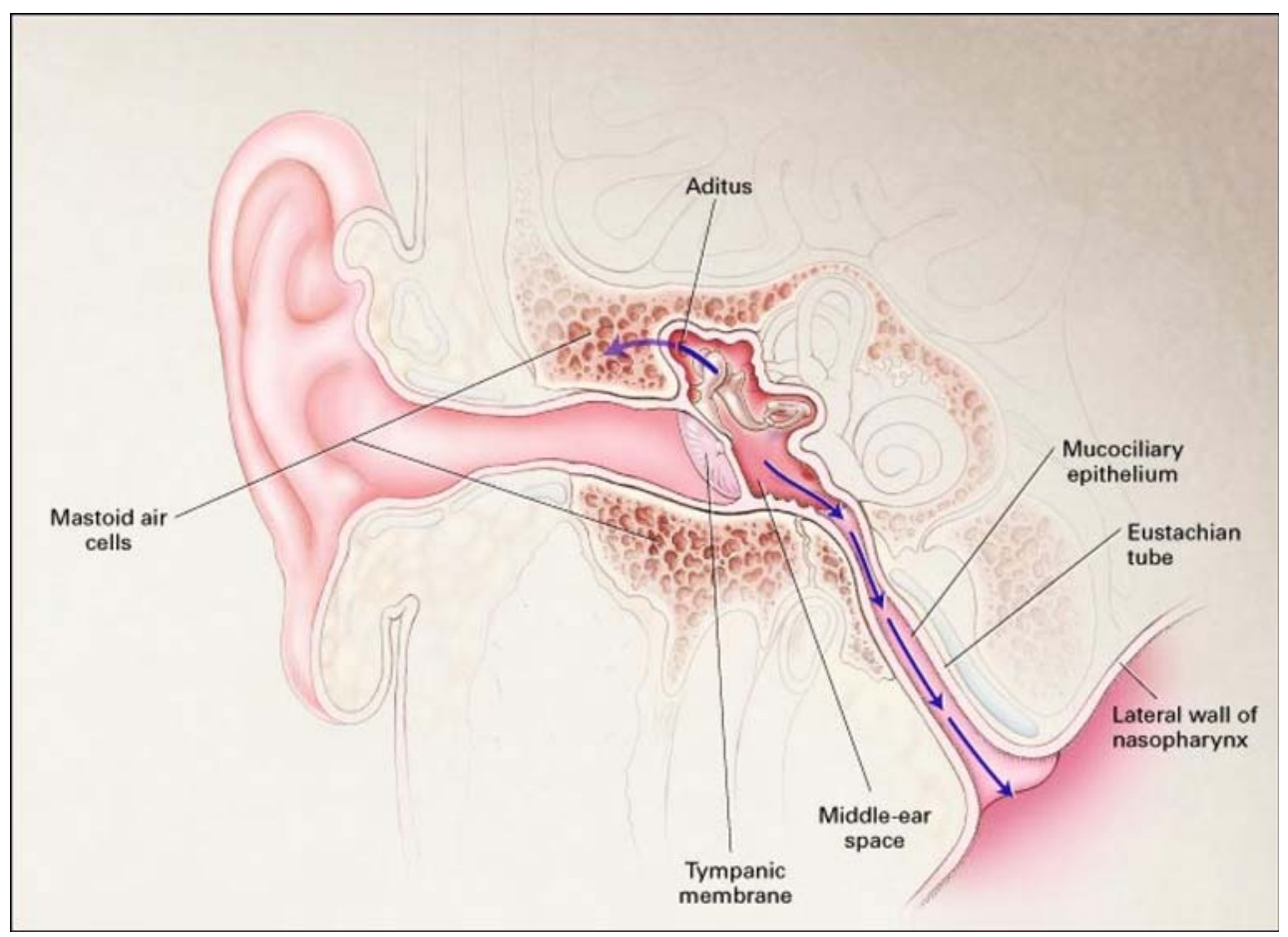


6 months and 12 years, did not receive an antibiotic for 2 weeks prior to the study. A positive bacterial culture was obtained in $54 \%$ of the children and respiratory viruses were identified in $32 \%$ of them; combined viral and bacterial infection was demonstrated in $12 \%$ of the samples.

Persistent otitis was documented in about $50 \%$ of the children with combined viral and bacterial infection in a prospective study of 271 children because viral infections contribute to the ET dysfunction [12].

Other risk factors

The immaturity of the immune system of young children makes them incapable of killing encapsulated bacteria. This, along with the ET dysfunction, explains the longlasting course of AOM as well as the high recurrence rate.

This is particularly important for infants attending day care centres $[37,38]$. It is sometimes necessary to withdraw these infants from these institutions during the winter to avoid recurrences. Additional risk factors are passive smoking, young siblings going to school and siblings with previous AOM episodes.

These factors were identified in a prospective study on 2,253 children aged 2 months to 2 years published in 1997 [37]. The proportion of patients developing at least one episode of OME was $79 \%$ at 12 months and $91 \%$ at 24 months. Breast feeding and exposure to tobacco smoke contributed little to the outcome, but a lower socioeconomic status and repeated exposure to other children at home or in day care centres were the most important risk factors.

Children with cleft palate are particularly prone to otitis and should be treated by early tympanostomy tube insertion [60].

\section{Complications: mastoiditis}

Mastoiditis should be treated by antibiotics according to the bacterial resistance and by temporarily inserting tympanostomy tubes to improve drainage [65] because of the narrow calibre of the aditus ad antrum. [22] (Fig. 4).

\section{Treatment}

General considerations

A "wait and see" approach has been advocated in the treatment of AOM in children mainly because of the increased antimicrobial resistance of bacteria causing respiratory infections [13]. Indeed, a meta-analysis of 5,400 children, aged 6 months to 18 years, and collected from 33 randomized trials concluded that there was a significant but modest impact of antibiotics on the primary control of AOM [45]. Similar results emerged from a subsequent study published by Damoiseaux et al. in 2000 [15]. This randomized double-blind prospective trial carried out by general practitioners in 240 children, aged 6 months to 2 years, showed that only 7 and maybe 8 of them needed antibiotics. Both studies, however, suffer from major flaws; the absence of long-term data, in particular the recurrence rate of AOM, and OME not being considered an end point. Moreover, the former study included patients with a very large age range and therefore blunted the effect of the critical age group of the patients below the age of 2 years. Indeed, over $70 \%$ of AOM patients present their first attack during the first year of life and over $90 \%$ within 2 years of age [35]. The visualisation of the tympanum in this age group is not always easy especially when cerumen obstructs the narrow external ear channel. Yet, as already mentioned above, bulging and redness of the tympanic membrane are important diagnostic signs of bacterial AOM [27, 39].

\section{Treatment of AOM}

The crucial role of the first attack of AOM makes the immediate administration of antibiotics mandatory in all patients with AOM with redness and a bulging tympanum (Table 1) [26]. A "wait and see" approach can only increase the inflammation and hence the ET dysfunction. The choice of the antibiotic must take into account the penetration in the middle ear and the type of bacteria involved. The

Table 1 Guidelines for treatment of AOM

\begin{tabular}{|c|c|c|}
\hline Episode & Signs or symptoms & Treatment or approach \\
\hline \multicolumn{3}{|c|}{ Children $<2$ years of age } \\
\hline \multicolumn{2}{|l|}{ First episode } & $\begin{array}{l}\text { Amoxicillin } 90 \mathrm{mg} / \mathrm{kg} \text { per day for at least } 10 \text { days according to the bacterial resistance } \\
\text { Weekly follow-up by tympanometry and pneumo-otoscopy }\end{array}$ \\
\hline \multirow[t]{2}{*}{$\begin{array}{l}\text { Recurrent } \\
\text { episode }\end{array}$} & With redness and bulging tympanum & $\begin{array}{l}\text { Amoxicillin or amoxicillin } 90 \mathrm{mg} / \mathrm{kg} \text { per day }+ \text { clavulanic acid } 6.4 \mathrm{mg} / \mathrm{kg} \text { per day } \\
\text { according to bacterial resistance }\end{array}$ \\
\hline & Without bulging & "Wait and see" approach \\
\hline \multicolumn{3}{|c|}{ Children $>2$ years of age } \\
\hline & $\begin{array}{l}\text { With redness and bulging tympanum } \\
\text { or otorrhoea }\end{array}$ & Same treatment as "recurrent episode" \\
\hline & Without evident bulging tympanum & "Wait and see" approach \\
\hline
\end{tabular}


penetration for amoxicillin-about $40 \%$ of the blood concentration-is much higher than for cephalosporins (about 20\%) and macrolides (about 10\%) but lower than for cotrimoxazole $(60 \%)$ [31]. The penetration of amoxicillin is not changed by the addition of clavulanate to amoxicillin $[10,52]$.

Because of the increased incidence of Streptococcus pneumoniae with intermediary resistance [57, 61], the dosage of amoxicillin should be doubled, i.e. $90 \mathrm{mg} / \mathrm{kg}$ per day given in three administrations as recommended by the Centers for Disease Control and Prevention [3].

Haemophilus influenzae is more likely to become $\beta$ lactamase positive after previous antibiotic administration [9]. Therefore, the addition of clavulanate - at a dose of $6.4 \mathrm{mg} / \mathrm{kg}$ per day-to amoxicillin makes sense. Most Moraxella catarrhalis strains are nowadays also $\beta$-lactamase positive [42].

The duration of the antibiotic treatment is a matter of discussion. For children less than 2 years of age, a 10-day course is reasonable. Pneumo-otoscopy and tympanometry can help to appreciate the permeability of the ET. Careful follow-up is necessary.

Nasopharyngeal aspirate cultures may give valuable results and are highly recommended in children remaining in day care centres or with a history of previous AOM episodes [28, 51].

For children more than 2 years of age the previously watchful guidelines can be maintained but some flexibility is recommended $[22,36]$.

Treatment of OME: tympanostomy tubes?

The approach to OME must take into account the natural history of spontaneous healing and the main complication which is temporary hearing impairment [1]. The absence of spontaneous healing after 6 weeks to 2 months in children over 2 years of age is an indication for a 10-day antibiotic course according to the results of the nasopharyngeal aspirate cultures. It is our experience that this approach has several advantages. First, the effect even temporarily on the hearing defect is frequently successful. Second, it decreases the recurrence of AOM by improving the ET functions and third, it allows postponement or avoidance of tympanostomy tube insertion, because improved hearing points to improved permeability of the ET.

The delay of 6 weeks or 2 months before treatment of OME (Table 2) is based on the duration of OME. Indeed, in a prospective study by Renko et al. [43] of 90 children with AOM, 0.6-7 years of age, treated with amoxicillin or cefuroxime axetil for 10 days, the mean duration of OME was 10.2 days (range: $1-58$ days); only 10 of 90 still had OME after 29-43 days.

In a long-term prospective study in 6,350 healthy infants treated according to specified guidelines, Paradise et al. [38] observed bilateral OME in only 5.6\% of the 161 children who had not received tympanostomy tubes at the age of 4 .

The indication to insert tubes is equivocal. The large prospective studies on 3,686 infants and young children by the Paradise group have shown the absence of or negligible effects of tympanostomies on developmental outcomes at 3-4 years [34, 37]. On the other hand, insertion of tympanostomy tubes during the first 3 years of life is associated with complications in at least $80 \%$ of the patients [63]. Tympanostomy can be a source of bacterial infections [24] and of tympanosclerosis.

Extensive reviews by Kubba et al. [25], Rosenfeld et al. [46], Rovers et al. [48] and the recent Cochrane Database by Lous et al. [30] concluded that there was only a small benefit of the conventional ventilation tube. The main reason for the poor results of tympanostomy tubes is the absence of effects on the ET dysfunction. It has never been demonstrated that tympanostomy tubes improve the functions of the ET.

The recommendations by the American Academy of Pediatrics [1] are to insert tubes in conditions with persisting hearing loss of more than $40 \mathrm{~dB}$ particularly

Table 2 Guidelines for treatment of OME. SMZ sulfamethoxazole, TMP trimethoprim

\begin{tabular}{|c|c|c|}
\hline Indication & Approach & Treatment \\
\hline Without deafness & "Watchful waiting" approach & \\
\hline With deafness & $\begin{array}{l}\text { After } 6 \text { weeks- } 2 \text { months } \\
\text { in children } \geq 2 \text { years }\end{array}$ & $\begin{array}{l}\text { Amoxicillin } 90 \mathrm{mg} / \mathrm{kg} \text { per day or amoxicillin } 90 \mathrm{mg} / \mathrm{kg} \text { per day }+ \text { clavulanic acid } \\
6.4 \mathrm{mg} / \mathrm{kg} \text { per day for } 10 \text { days according to the results of the bacterial resistance } \\
\text { No swimming }\end{array}$ \\
\hline \multirow{2}{*}{$\begin{array}{l}\text { Recurrent OME or OME } \\
\text { of long duration }\end{array}$} & & Azithromycin $10 \mathrm{mg} / \mathrm{kg}$ per day, 3 days/week for 4 weeks \\
\hline & & $\begin{array}{l}\text { Cotrimoxazole } 30 \mathrm{mg} \mathrm{SMZ}+6 \mathrm{mg} \mathrm{TMP} / \mathrm{kg} \text { per day according to the results of the } \\
\text { bacterial resistance } \\
\text { Adenoidectomy in children } \geq 3 \text { years of age with nasopharyngeal obstruction and } \\
\text { recurrent adenoiditis } \\
\text { No swimming }\end{array}$ \\
\hline
\end{tabular}


with posterosuperior retraction pockets, ossicular erosions and adhesive atelectasis because of the increase of structural damage with effusion duration.

Watchful waiting for 3-6 months in the winter period seems advisable in children with mild hearing deficit.

Adenoidectomy should be considered in children $\geq 3$ years of age with nasopharyngeal obstruction and recurrent adenoiditis [45].

\section{Vaccination}

The effects of pneumococcal vaccination on recurrent AOM have been studied extensively. In a randomized controlled trial by Brouwer et al. [6] in 383 children, aged 1-7 years, with recurrent AOM, the effects in 190 children treated with heptavalent pneumococcal vaccine were compared with 193 children receiving hepatitis A or B vaccines. The study concluded that there was no beneficial effect. A similar conclusion was drawn from a study by Van Kempen et al. [62] in 74 children aged 1-7 years and in the Cochrane Database by Straetemans et al. [56].

A shift of the causative pathogen has been observed from Streptococcus pneumoniae to Haemophilus influenzae or to other strains of pneumococci than the ones included in the vaccine $[20,59]$. A slight reduction of the incidence of AOM of $6-8 \%$ was observed in the USA [7].

\section{Infants and prematures}

A high incidence of OME has been observed in neonatal intensive care units due to the nasally placed tubes for ventilatory assistance. It has been suggested that immune immaturity with impaired neuromotor function predisposes to this complication [17]. Vaccination with the heptavalent pneumococcal vaccine has been advocated in premature babies and neonates [19], but this study does not provide information on the actual AOM prevalence in a control group receiving only hepatitis $\mathrm{B}$ vaccine. It should be remembered that meconium aspiration into the entry of the middle ear is associated with increased risk of AOM and therefore early nasopharyngeal suction is mandatory [29].

Acknowledgements We express our thanks to Henley JO and the Editors of the New England Journal of Medicine for their kind permission to use the figure published in the issue 2002, 347:1169.

We also express our thanks to Bluestone CD and Stool SE $(\dagger)$ and W.B. Saunders Company for their kind permission to use the figures published in Pediatric Otolaryngology (1983).

\section{References}

1. American Academy of Family Physicians, American Academy of Otolaryngology-Head and Neck Surgery, American Academy of
Pediatrics Subcommittee on Otitis Media With Effusion (2004) Otitis media with effusion. Pediatrics 113:1412-1429

2. Andrade MA, Hoberman A, Glustein J, Paradise JL, Wald ER (1998) Acute otitis media in children with bronchiolitis. Pediatrics 101:617-619

3. Bauchner H, Marchant CD, Bisbee A, Heeren T, Wang B, McCabe M, Pelton S, Boston-Based Pediatric Research Group (2006) Effectiveness of Centers for Disease Control and Prevention recommendations for outcomes of acute otitis media. Pediatrics 117:1009-1017

4. Bingen E, Cohen R, Jourenkova N, Gehanno P (2005) Epidemiologic study of conjunctivitis-otitis syndrome. Pediatr Infect Dis J 24:731-732

5. Bluestone CD, Klein JO (1983) Otitis media with effusion, atelectasis, and Eustachian tube dysfunction. In: Bluestone CD, Stool SE (eds) Pediatric otolaryngology. Saunders, Philadelphia, pp 356-512

6. Brouwer CN, Maille AR, Rovers MM, Veenhoven RH, Grobbee DE, Sanders EA, Schilder AG (2005) Effect of pneumococcal vaccination on quality of life in children with recurrent acute otitis media: a randomized, controlled trial. Pediatrics 115:273-279

7. Brunton S (2006) Current face of acute otitis media: microbiology and prevalence resulting from widespread use of heptavalent pneumococcal conjugate vaccine. Clin Ther 28:118-123

8. Bulut Y, Güven M, Otlu B, Yenisehirli G, Aladag I, Eyibilen A, Dogru S (2007) Acute otitis media and respiratory viruses. Eur J Pediatr 166:223-228. DOI 10.1007/s00431-006-0233-x

9. Buznach N, Dagan R, Greenberg D (2005) Clinical and bacterial characteristics of acute bacterial conjunctivitis in children in the antibiotic resistance era. Pediatr Infect Dis J 24:823-828

10. Canafax DM, Yuan Z, Chonmaitree T, Deka K, Russlie HQ, Giebink GS (1998) Amoxicillin middle ear fluid penetration and pharmacokinetics in children with acute otitis media. Pediatr Infect Dis J 17:149-156

11. Casado-Flores J, Aristegui J, de Liria CR, Martinon JM, Fernandez C; Spanish Pneumococcal Meningitis Study Group (2006) Clinical data and factors associated with poor outcome in pneumococcal meningitis. Eur J Pediatr 165:285-289

12. Chonmaitree T, Owen MJ, Patel JA, Hedgpeth D, Horlick D, Howie VM (1992) Effect of viral respiratory tract infection on outcome of acute otitis media. J Pediatr 120:856-862

13. Corbeel L (2005) The 'wait and see' approach of acute otitis media. Eur J Pediatr 164:1-2

14. Corbeel L (2006) Pneumococcal meningitis and otitis media. Eur J Pediatr 165:283-284

15. Damoiseaux RA, van Balen FA, Hoes AW, Verheij TJ, de Melker RA (2000) Primary care based randomised, double blind trial of amoxicillin versus placebo for acute otitis media in children aged under 2 years. BMJ 320:350-354

16. Damoiseaux RA, Rovers MM, Van Balen FA, Hoes AW, de Melker RA (2006) Long-term prognosis of acute otitis media in infancy: determinants of recurrent acute otitis media and persistent middle ear effusion. Fam Pract 23:40-45

17. Engel J, Mahler E, Anteunis L, Marres E, Zielhuis G (2001) Why are NICU infants at risk for chronic otitis media with effusion? Int J Pediatr Otorhinolaryngol 57:137-144

18. Fleming DM, Pannell RS, Elliot AJ, Cross KW (2005) Respiratory illness associated with influenza and respiratory syncytial virus infection. Arch Dis Child 90:741-746

19. Fletcher MA, Fritzell B (2006) Brief review of the clinical effectiveness of PREVENAR $\left({ }^{\circledR}\right)$ against otitis media. Vaccine Sep 20 (epub ahead of print)

20. Garbutt J, Rosenbloom I, Wu J, Storch GA (2006) Empiric first-line antibiotic treatment of acute otitis in the era of the heptavalent pneumococcal conjugate vaccine. Pediatrics 117:e1087-e1094 
21. Heikkinen T, Thint M, Chonmaitree T (1999) Prevalence of various respiratory viruses in the middle ear during acute otitis media. N Engl J Med 340:260-264

22. Hendley JO (2002) Otitis media. N Engl J Med 347:1169-1174

23. Hotomi M, Yamanaka N, Samukawa T, Suzumot M, Sakai A, Shimada J, Ikeda Y, Faden H (2005) Treatment and outcome of severe and non-severe acute otitis media. Eur J Pediatr 164:3-8

24. Ingels K, Rovers MM, van der Wilt GJ, Zielhuis GA (2005) Ventilation tubes in infants increase the risk of otorrhoea and antibiotic usage. B-ENT 1:173-176

25. Kubba H, Pearson JP, Birchall JP (2000) The aetiology of otitis media with effusion: a review. Clin Otolaryngol Allied Sci 25:181

26. Leach AJ, Morris PS (2006) Antibiotics for the prevention of acute and chronic suppurative otitis media in children. Cochrane Database Syst Rev 18:CD004401

27. Leibovitz E, Satran R, Piglansky L, Raiz S, Press J, Leiberman A, Dagan R (2003) Can acute otitis media caused by Haemophilus influenzae be distinguished from that caused by Streptococcus pneumoniae? Pediatr Infect Dis J 22:509-515

28. Libson S, Dagan R, Greenberg D, Porat N, Trepler R, Leiberman A, Leibovitz E (2005) Nasopharyngeal carriage of Streptococcus pneumoniae at the completion of successful antibiotic treatment of acute otitis media predisposes to early clinical recurrence. J Infect Dis 191:1869-1875

29. Lilja M, Palva T, Ramsay H, Laitinen K, Andersson S (2006) Meconium contaminated amniotic fluid and infant otitis media. Is it a risk factor in children surviving aspiration and initial distress of respiration? Int J Pediatr Otorhinolaryngol 70:655-662

30. Lous J, Burton MJ, Felding JU, Ovesen T, Rovers MM, Williamson I (2005) Grommets (ventilation tubes) for hearing loss associated with otitis media with effusion in children. Cochrane Database Syst Rev 1:CD001801

31. McLinn S (1978) Comparative study of cefaclor, a new cephalosporin, and amoxicillin in the treatment of acute otitis media in children. Curr Chemother 1:123-125

32. Monobe H, Ishibashi T, Normura Y, Shinogami M, Yano J (2003) Role of respiratory viruses in children with acute otitis media. Int J Pediatr Otorhinolaryngol 67:801-806

33. Nokso-Koivisto J, Raty R, Blomqvist S, Kleemola M, Syrjanen R, Pitkaranta A, Kilpi T, Hovi T (2004) Presence of specific viruses in the middle ear fluids and respiratory secretions of young children with acute otitis media. J Med Virol 72:241-248

34. Paradise JL, Feldman HM, Campbell TF, Dollaghan CA, Colburn DK, Bernard BS, Rockette HE, Janosky JE, Pitcairn DL, Sabo DL, Kurs-Lasky M, Smith CG (2001) Effects of early or delayed insertion of tympanostomy tubes for persistent otitis media on developmental outcomes at the age of three years. N Engl J Med 344:1179-1187

35. Paradise JL (1980) Otitis media in infants and children. Pediatrics 65:917-943

36. Paradise JL (1995) Treatment guidelines for otitis media: the need for breadth and flexibility. Pediatr Infect Dis J 14:429-435

37. Paradise JL, Rockette HE, Colborn DK, Bernard BS, Smith CG, Kurs-Lasky M, Janosky JE (1997) Otitis media in 2253 Pittsburgh-area infants: prevalence and risk factors during the first two years of life. Pediatrics 99:318-333

38. Paradise JL, Dollaghan CA, Campbell TF, Feldman HM, Bernard BS, Colborn DK, Rockette HE, Janosky JE, Pitcairn DL, KursLasky M, Sabo DL, Smith CG (2003) Otitis media and tympanostomy tube insertion during the first three years of life: developmental outcomes at the age of four years. Pediatrics 112:265-277

39. Pellman H (2005) Thoughts on the American Academy of Pediatrics/American Academy of Family Physicians Clinical Practice Guideline on acute otitis media: a different perspective. Pediatrics 115:1443-1444
40. Pelton SI (2005) Otitis media: re-evaluation of diagnosis and treatment in the era of antimicrobial resistance, pneumococcal conjugate vaccine, and evolving morbidity. Pediatr Clin North Am $52: 711-728$

41. Pitkaranta A, Hayden FG (1999) Respiratory viruses and otitis media. N Engl J Med 340:2001-2002

42. Pottumarthy S, Sader HS, Fritsche TR, Jones RN (2005) Susceptibility patterns for amoxicillin/clavulanate tests mimicking the licensed formulations and pharmacokinetic relationships: do the MIC obtained with 2:1 ratio testing accurately reflect activity against beta-lactamase-producing strains of Haemophilus influenzae and Moraxella catarrhalis? Diagn Microbiol Infect Dis $53: 225-231$

43. Renko M, Kontiokari T, Jounio-Ervasti K, Rantala H, Uhari M (2006) Disappearance of middle ear effusion in acute otitis media monitored daily with tympanometry. Acta Paediatr 95:359-363

44. Revai K, McCormick DP, Patel J, Grady JJ, Saeed K, Chonmaitree $\mathrm{T}$ (2006) Effect of pneumococcal conjugate vaccine on nasopharyngeal bacterial colonization during acute otitis media. Pediatrics 117:1823-1829

45. Rosenfeld RM, Vertrees JE, Carr J, Cipolle RJ, Uden DL, Giebink GS, Canafax DM (1994) Clinical efficacy of antimicrobial drugs for acute otitis media: metaanalysis of 5400 children from thirtythree randomized trials. J Pediatr 124:355-367

46. Rosenfeld RM, Culpepper L, Doyle KJ, Grundfast KM, Hoberman A, Kenna MA, Lieberthal AS, Mahoney M, Wahl RA, Woods CR Jr, Yawn B, American Academy of Pediatrics Subcommittee on Otitis Media with Effusion, American Academy of Family Physicians, American Academy of Otolaryngology-Head and Neck Surgery (2004) Clinical practice guideline: otitis media with effusion. Otolaryngol Head Neck Surg 130:S95-S118

47. Rovers MM, Schilder AG, Zielhuis GA, Rosenfeld RN (2004) Otitis media. Lancet 363:465-473

48. Rovers MM, Black N, Browning GG, Maw R, Zielhuis GA, Haggard MP (2005) Grommets in otitis media with effusion: an individual patient data meta-analysis. Arch Dis Child 90:480-485

49. Rovers MM, Glasziou P, Appelman CL, Burke P, McCormick DP, Damoiseaux RA, Gaboury I, Little P, Hoes AW (2006) Antibiotics for acute otitis media: a meta-analysis with individual patient data. Lancet 368:1429-1435

50. Sagai S, Suetake M, Yano H, Yoshida M, Ohyama K, Endo H, Takayanagi R, Nishimura H, Kobayashi T (2004) Relationship between respiratory syncytial virus infection and acute otitis media in children. Auris Nasus Larynx 31:341-345

51. Samuelson A, Freijd A, Jonasson J, Lindberg AA (1995) Turnover of nonencapsulated Haemophilus influenzae in the nasopharynges of otitis-prone children. J Clin Microbiol 33:2027-2031

52. Scaglione F, Demartini G, Dugnani S, Arcidiacono MM, Pintucci JP, Fraschini F (1999) Interpretation of middle ear fluid concentrations of antibiotics: comparison between ceftibuten, cefixime and azithromycin. Br J Clin Pharmacol 47:267-271

53. Schildgen O, Gelkowski T, Glatzel T, Schuster J, Simon A (2005) Frequency of human metapneumovirus in the upper respiratory tract of children with symptoms of an acute otitis media. Eur J Pediatr 164:400-401

54. Smith CG, Paradise JL, Sabo DL, Rockette HE, Kurs-Lasky M, Bernard BS, Colborn DK (2006) Tympanometric findings and the probability of middle-ear effusion in 3686 infants and young children. Pediatrics 118:1-13

55. Spinola SM, Peacock J, Denny FW, Smith DL, Cannon JG (1986) Epidemiology of colonization by nontypable Haemophilus influenzae in children: a longitudinal study. J Infect Dis 154:100-109

56. Straetemans M, Sanders EA, Veenhoven RH, Schilder AG, Damoiseaux RA, Zielhuis GA (2004) Pneumococcal vaccines 
for preventing otitis media. Cochrane Database Syst Rev 1: CD001480

57. Syrjanen RK, Auranen KJ, Leino TM, Kilpi TM, Makela PH (2005) Pneumococcal acute otitis media in relation to pneumococcal nasopharyngeal carriage. Pediatr Infect Dis J 24:801-806

58. Syrjanen RK, Herva EE, Makela PH, Puhakka HJ, Auranen KJ, Takala AK, Kilpi TM (2006) The value of nasopharyngeal culture in predicting the etiology of acute otitis media in children less than two years of age. Pediatr Infect Dis J 25: 1032-1036

59. Toltzis P, Jacobs MR (2005) The epidemiology of childhood pneumococcal disease in the United States in the era of conjugate vaccine use. Infect Dis Clin North Am 19:629-645

60. Valtonen H, Dietz A, Qvarnberg Y (2005) Long-term clinical, audiologic, and radiologic outcomes in palate cleft children treated with early tympanostomy for otitis media with effusion: a controlled prospective study. Laryngoscope 115:1512-1516

61. van Kempen MJ, Vaneechoutte M, Claeys G, Verschraegen GL, Vermeiren J, Dhooge IJ (2004) Antibiotic susceptibility of acute otitis media pathogens in otitis-prone Belgian children. Eur J Pediatr 163:524-529

62. van Kempen MJ, Vermeiren JS, Vaneechoutte M, Claeys G, Veenhoven RH, Rijkers GT, Sanders EA, Dhooge IJ (2006) Pneumococcal conjugate vaccination in children with recurrent acute otitis media: a therapeutic alternative? Int J Pediatr Otorhinolaryngol 70:275-285

63. Vlastarakos PV, Nikolopoulos TP, Korres S, Tavoulari E, Tzagaroulakis A, Ferekidis E (2007) Grommets in otitis media with effusion: the most frequent operation in children. But does it have significant complications? Eur J Pediatr. DOI 10.1007/ s00431-006-0367-x

64. Yano H, Suetake M, Endo H, Takayanagi R, Numata M, Ohyama K, Sagai S, Okitsu N, Okamoto M, Nishimura H, Kobayashi T (2005) Isolation of measles virus from middle ear fluid of infants with acute otitis media. J Infect 51:e237-e240

65. Zanetti D, Nassif N (2006) Indications for surgery in acute mastoiditis and their complications in children. Int $\mathrm{J}$ Pediatr Otorhinolaryngol 70:1175-1182 